\title{
The Motivation of Kang Jalal Keeping on Sufistic Thoughts
}

\author{
Muhammad \\ Ushuluddin Faculty, State Islamic University of Medan (UINSU), Medan, Indonesia
}

\begin{abstract}
The aims of this study is to find out the motivation of kang jalal keeping on sufistic thoughts. This study used qualitative research method. The result in this study shows that Kang Jalal's motivation to pursue Sufism was influenced by several factors: Psychological factors, preaching with Sufistic thinking; Sufistic ulama thought factor, Jalal likes to read Sufism literature; inter-school pro-counter factors, Jalal being neutral in thinking about differences between schools; the factor of spiritual crisis in modern society, it requires living comprehension, both vertically and horizontally, hablum minallah, hablum minannas and even hablum minal kauni perfectly.
\end{abstract}

Keywords : motivation; Kang Jalal; sufistic; Islamic study

\section{Introduction}

Islam is a universal religion, the teachings it carries quite complete and perfect, covering zahiri and batini dimensions. The zahiriah aspect is called syariah spoken of in fikih, whereas the inner aspect is ruhaniah discussed in Sufism. Muslims are already supposed to live up to and gradually disgrace both dimensions of the teaching. In the practice of everyday life it is inevitable that in general Muslims seem to take precedence over the zahiri aspect, whereas the batini aspect is less attention, as if neglected by various reasons. (Ali Maskun, Sufism As Reverence, p. 105). On the subject of religious delusion through the aspect of this batini, it is seen as an important aspect for a believer in order to obtain a high degree in the sight of Allah.

Sufism is a mental attitude that can preserve the sanctity of man from worldly influences, so that his soul remains in a state of polytheism and all its activeness is always fixed to something that can relate itself to Allah. To acquire such clean and holy ruhaniah mental attitudes, the human soul is required exercises with various civic ritual worship charities and living as a zahid and 'abid. All the primogeniture and activity it performs has the value of worship and is solely fixed to Allah Swt, so that in mankind shall be born a noble and close apostle to his Allah. (Usman Said, Introduction to the Science of the Sufism, p. 13-15).

Traditional Sufism practices can be implemented, but contemporary Sufism practices need to be developed in the life of this sophisticated and modern society, so that they can understand, accept and practice Sufism in their lives. Thus, Sufism can live and thrive in life in today's society, if not, it is feared that Sufism will gradually disappear in the life of mankind, because it loses its relevance in this modern age. Based on the progress of today's society, Jalaluddin Rachmat seeks to adapt the methods and practices of Sufistics life in accordance with the times.

\section{Review of Literature}

In the Islamic world, for example, the term Sufism is actually long enough to be known, even at the end of the second century or the beginning of the third century Hijri, Sufism has begun to be practiced by Muslims, the practice of zuhud and ta'at in worshiping Allah Almighty. However, the origin and elements that form the basis of the formation of Sufism, is still a matter of debate among experts, including among Muslims themselves. Among Sufistic and Orientalist experts, the origin of Sufism came from outside the religion of Islam. Sufism appeared influenced by the teachings of Christianity, Hindu Buddhism, Persia, Greek philosophy and Islam itself. This is synonymous with the agreement of the western orientalists, 
they argue that the source of the birth of Sufism was from the five agreed elements, namely: the Islamic element, the Christian element, the Greek element, the Hindu Buddhist element and the Persian element. (Abuddin Nata, Akhlak Tasawuf, p. 181). These five elements can be briefly explained as follows:

Elements of Christianity: In Christianity it is known by the idea of staying away from the crowded world and seclusion in monasteries. The monks who lived were secluded in the desert of Arabia. The lights that they installed at night became a guide for the last caravan, their simple tents became a shelter for those who were overnight, and their generosity fed the starving travelers. The Islamic zahids and Sufis shunned worldly life, chose a simple life, secluded themselves from the life of the crowd and provided food for hungry travelers, so that the practices of Christian monks were said to influence the behavior and patterns of life of Muslims, which later was called Sufism (at- Tafzani, Sufi, Usmani, pp. 22-34).

Most Arabs really like the ways of pastors when they do spiritual practice and worship. Sufism in the days of ignorance dikatan is the forerunner of Christian teaching. The tendency of ascetic life and the pleasure of silence are closely related to the theories of Christian teaching. The role of the priests as teachers who give instructions and means of ascetic life of Islamic Sufi. Sheep clothing worn by zahids or Sufis in Islam is a cultural dress of Christians. Teachings that say love for Allah also comes from Christianity, this is in accordance with the story of the dialogue of Jesus with a group of people who met him. They ask about love for Allah, then Jesus answers that you are a human being closest to Allah (Kailani, Fi attasawwuf, p. 21).

The indigent attitude of life for Sufis in Islam stems from Christianity. The pleasure of the quiet life, remembering God and other ascetic practices, can be traced and turned towards the same original source. Judaism and Christianity, also influence the mindset in Islam. Understanding that developed in Islam such as the Muktazilah was taken from the thoughts of Lubeit bin A'sham, a Jew who once terrorized Muhammad. With his black magic, A'sham mentions that the Torah was created by humans, so the people behind him preach that the Qur'an was also created by humans (Kailani, Fi at-Tasawwuf, p. 21). Such as the attitude of the destitute life, resignation, the role of the Shaykh, refraining from being married and musyahadah and holding a dialogue with God are included Christian teachings mentioned and explained in the Gospels (Nasution, Philosophy, p. 58).

Elements of Hinduism and Buddhism: The system of belief and Sufism in Hinduism has similarities, such as the attitude of life of poverty in Sufism. Ways of worshiping Hinduism and mujahadah in the teachings of Sufism have similarities. The teachings of reincarnation and escape from world life are included in the teachings of Hindu-Buddhist religion, which in Sufism is termed as the union of beings by remembering Allah. The teachings of Nirvana in Hinduism, also have similarities with the teachings of al-fana in Sufism. Nirvana in Buddhism, teaches its people to leave the world and enter a life of contemplation. The command to leave the world and approach God to achieve the union of Atman and Brahmin is the teaching of Hinduism (Nasution, Philosophy, p. 59).

Some Orientalists say that Islamic Sufism is strongly colored by Hinduism, in addition to the teachings of Christianity and Neo Platinus. However, many researchers from Islam refuse to say that Sufism comes from Hindu-Buddhist religion. If it is accepted that the teachings of Sufism come from Hindu-Buddhist, it means that during the time of the Prophet Muhammad Hindu-Buddhist teachings have developed to Mecca. In fact, throughout the history of religion there has not been, because Hindu-Buddhist religion existed when Islam was born, and indeed 
there has been no statement from experts about the influence of the Hinduism -Buddhist religion on the behavior of Muslims in the early days of Islam.

The Persian element: For a long time actually between the Arabs and Persians had relations in various fields, both in the fields of politics, thought, society and literature. However, throughout the research, strong arguments have not yet been found that the Persian spiritual life had entered Arabic, but in the spiritual life of the Arabs entered Persia, so that the Persians were known as Sufism experts. So far, Persia is known as a region that gave birth to prominent and brilliant Sufis, such as Abu Yazid of Bistam.

\section{Discussion}

\subsection{Sufistic Kang Jalal Thinking}

As it is known that Kang Jalal is active in preaching and recitation activities in the homeland. Jalal's early story of preaching, began when he was active in the Persis organization, and joined the Muhammadiyah Organization, then he received guidance in Darul Arqam, a training ground for Muhammadiyah cadres. After receiving training, Jalal became a fanatical Muhammadiyah cadre. Armed with the Decree of the Muhammadiyah Tarjih Council, Jalal began to preach, fighting for the vision of Muhammadiyah that he worked on. Kang Jalal's presence caused prolonged conflict and tension in his hometown, the majority of which were Nahdatul Ulama. (Mercy, Bridging, p. 143).

As a young preacher, Jalal's lectures initially received constant criticism from the elderly, so that Jalal had to be extra strict to prepare himself to dismiss the accusations directed at him. Especially after Jalal returned from America, his activities were thicker in the field of da'wah, so it was not surprising that he was known as an Islamic intellectual, rather than as a communication expert. Jalal's preaching activities began to expand and enter the main campuses in Bandung, and in several cities in Java and outside Java, especially in the Salman Mosque, the ITB campus. Bandung (Mercy, Bridging, pp. 147-148).

For the sake of maintaining ukhuwah Islamiyah and harmony among fellow believers, Jalal tried to change the method and orientation of his da'wah from fikhiyah material to a preaching sufistic nuance. And in connection with his new discourse, Jalal is equipped with knowledge that has the nuances of Sufism. Many things influenced Jalal's thinking, so he plunged into the world of Sufism. According to him, the material of Sufism is very broad, the nuances are quite deep, the books are quite numerous and will not be finished being read and studied in a short amount of time. Religion with Sufism, he will feel the warmth, the leniency in religion, because the Sufis in seeing various problems are not black and white, right wrong, kosher forbidden and hell heaven, but the Sufis see the meaning and nature behind all the events that occur (Rosyidi , Da'wah, 118).

Many factors influence Jalal's thinking, so he plunged into the world of Sufism, including being influenced by Jalal's psychological factors, the influence of the thoughts of Sufi scholars and pro-counter between schools of Islam, spiritual crises in modern society, including Sunni and Shi'a understandings, Asy'ariah and Mu'tazilah, even between the Nahdiyin and Muhammadiyah understandings, and so on. The factors that influence Jalal to explore Sufistic thinking include: 


\subsubsection{Effects of Psychological Factors}

As has been said before that Jalaluddin Rachmat is a famous preacher who counts enough on the island of Java. With a capital of scientific specialization in the field of communication and high rhetoric, lectures and lectures delivered by Jalal, made the public interested and fascinated by his lectures. According to Jalal, the experience was a very valuable teacher, learning from the experiences he had experienced, scathing criticism and controversy of thought that led to the blocking of his activities as an active preacher in Bandung.

Jalal's lectures delivered to the community initially focused more on the aspects of fiqh and thought nuanced in Muhammadiyah's understanding, so that Jalal received sharp criticism from the majority of his community, especially from the Nahdiyin, who were already wellestablished with their professed understanding. Because Jalal on various occasions his lecture introduced a new understanding, which was as if Jalal was suing an old understanding that was already established. To avoid further disputes, the community finally agreed to build their respective mosques in their hometown. (Mercy, Bridging, p. 147). Although Jalal found a big challenge in conveying his missionary vision, Jalal's intentions and zeal to preach in various places never failed and faded. In fact, thanks to his tenacity and rhetorical ability that can touch the hearts of the public, has been able to deliver Jalal as a reliable preacher until now. The success of Jalal on the da'wah stage is increasingly widely known by the people of Bandung, especially after he was trusted to fill lectures at the Salman Mosque Institute of Technology Bandung (ITB) by displaying various new Islamic ideas and visions, conveyed through lectures, discussions, seminars and writings through various the media became the attention of many, coupled with his charming rhetoric, making Jalal a new figure among young Islamic intellectuals who replaced the figure of Imanuddin Abdulrahim, who continued his doctoral studies in America. In fact, according to Imanuddin's confession, Salman's young people had broken up into two groups, namely the Nurcholish Madjid group and the Jalaluddin Rakhmat group (Rakhmat, Bridging, p. 148).

The story of Jalal's preaching journey, at first turned out to be not smooth, his preaching messages that led to the spirit of renewal, such as the need for the pillars of Islam coupled with amar makruf nahi nunkar, openness of the school and the defense of justice for the weak, received positive responses from young people. However, Jalal's ideas received a negative response from senior clerics, they assessed that Jalal's lectures often unsettled the public, and he was also accused of being an agent of mut'ah marriage and a leading figure in Shiite development in Indonesia (Grace, Note Kang Jalal, p. 153).

And the peak of suspicion and anger of the scholars, in 1985, Jalal was summoned by the Indonesian Ulema Council in Bandung to clarify all of the contents of his preaching messages deemed to deviate from the established establishment of the community. The completion of the Jalal case was decided by the court that the name Jalal was deleted from the lecture and sermon schedule throughout the city of Bandung (Rachmat, Bridging, p. 149).

\subsubsection{Influence of Sufistic Ulema Thought}

Jalaluddin Rachmat is an active person in the world of $d a^{\prime} w a h$, even he is more active as a preacher than as a communication expert. Since the $70 \mathrm{~s}$, Jalal has been known as a controversial preacher, the preaching material delivered by Jalal is more oriented towards fiqh understanding. Preaching in this fiqh material takes place between the $70 \mathrm{~s}$ to the $85 \mathrm{~s}$. As someone who likes to deliver propaganda material with new things. His lectures are often responded to by Muslim scholars and scholars, because the content of his lectures is considered 
to be contrary to the established understanding of society. Jalal is indeed a Muslim intellectual figure who is very fond of dialogue or debate with anyone on various matters, especially in matters relating to religion. When Jalal preached with fiqh material, he often and liked to debate with the scholars, and he always won the debate.

Jalal's experience in delivering lectures in fiqh material caused many obstacles that led to the breakdown of Islamic brotherhood between each other. Many scholars do not have an open attitude and are not ready to accept the khilafiah. Even though that opinion is the result of human's consent, it can be right and it can be wrong, why should fight in the matter of furu'iyah. Supposedly for Muslims, the issue of khilafiah can be used as a mercy in applying the mind in things that can bring progress and benefit to Muslims themselves universally, not differences of opinion make Muslims actually break and even spur enmity and even mutual kill between people.

As was stated earlier that Jalal's interest in Sufism had begun since his youth, but his perseverance only began when he came in contact with Shi'a books, especially when he was invited to attend an Islamic Conference in Colombo, in 1984, together with 1984 his friends like Haidar Bagir from ITB and KH Endang Saefuddin Anshary, MA. And from that meeting, Jalal obtained Shi'a books and deepened the thought of Shi'ite figures, such as Ali Shari'ati, Muhammad Iqbal, Murthadha Mutahhri (Mercy, Bridging, pp. 150-151).

From the beginning of Jalal's acquaintance with Shi'ite figures and their works, he diligently explored the ideas and thoughts of Iranian thinkers, whose connotations were Shiite, such as those of Shari'ati, Murthadha Mutahhari and even the thoughts of Imam Khomeini himself (Malik and Ibrahim, p. 292). Ali Shari'ati's ideas and thoughts were explored by Jalal through his writings, then Jalal argued that Ali Shari'ati's ideas and thoughts were considered less profound, so he was more interested in Murthadha Motahhari's thoughts.

According to him, Mutahhari's thought was more in-depth and suitable to be developed, because Mutahhari was a very open and non-sectarian Shiite thinker, Jalal was raised in a traditional education system, but he opened himself to the treasures of Western thought. His admiration for Mutahhari was due to Jalal combining activism and intellectualism. So besides being an intellectual, leader, writer, he is also an activist (Malik and Ibrahim, p. 307). Based on Mutahhari's open minded and non-sectarian mindset and privileges, Jalal established the Mutahhari Foundation, which was named the foundation of the name Mutahhari. And with that institution, Jalal wanted to show how tolerance and the spirit of ukhuwah could be built by reflecting on his role models (Malik and Ibrahim, Zaman, p. 292).

\subsubsection{Pro and con between Mazhab}

Sufism is one of the branches of the science of Islam commonly practiced by Sufis and the tarekats. If the fuqahas speak outward or syar'iah matters, then the Sufis beside outward matters, they speak matters related to inner or Sufism. According to the Sufis' understanding, the implementation of syar'iah such as prayer, fasting, alms and hajj is considered rudimentary, when not accompanied by the ways and doctrines of syar'iah preaching as intended by Sufism teachings. The implementation of syar'iah which is intended by the jurists as outlined in the science of fiqh is considered to be imperfect, because it is still in the form of the implementation of outward worship only, and not yet in the inner form that is demanded by the ways of worship in Islam, because all worship performed by a believer must be in accordance with sincere intentions solely because of Allah, which Jalaluddin Rahmat mentioned from because of Allah and solely for Allah (Grace, Devotional, p. 94). 
Jalal is a Muslim scholar and intellectual who is concerned with various issues that are developing, both in the fields of education, politics, social and Islamic thought in general. In the field of Islamic science, Jalal was very interested in studying the field of Sufism. He views Sufism or Sufism as an important part and a large influence on the religious life of Muslims. With a deep understanding of Sufism, a Muslim's awareness of Allah will be born. Jalal's involvement speaks in a variety of matters that have developed in Islam, solely due to his sense of responsibility and concern for the unfavorable condition of Muslims in various matters today, especially concerning differences in views about the schools and understandings that develop in Islam, which sometimes lead to the fracture of ukhuwah Islamiyah and the fading of the sense of friendship between fellow Muslims in general and Indonesian Muslims in particular.

The mazhab comes from the Arabic root word zahaba, which means to go or follow the opinions of others. The school of isim derives from the word zahaba, which means a place of reference, which then develops into a kind of fiqh package based on the results of ijtihad of the ulama. In Islam there are four major mazhab namely the Shafi'i, Hanafi, Hambali and Maliki mazhab. The differences in schools arose because of differences in the interpretation of the verses of the Qur'an and the Hadith. The differences in the narration of the hadith, and the differences in the usul of fiqh which result in differences in the procedure of drawing legal conclusions. In fact the differences of opinion had begun to occur in the time of the Prophet himself between Umar bin Khattab and Abu Bakar about the prayer. Abu Bakar performed witir prayers before going to bed, while Umar did them after sleeping. This difference occurred because Abu Bakar was a careful person, and Umar was a person of strong will (Grace, Alternative Islam, pp. 231-233).

Actually that mazhab is not bad, Islam gives freedom of thought and expresses his opinion. Dissent at the Mujtahid level does not become a problem, but when the difference reaches the lower levels or the lay person becomes a problem that is vulnerable to quarrels and division between people. The high priests of the four schools of thought, they differed in many ways, but they never fought, they prayed together in congregation.

The difference in views and understandings between them is considered a mercy and does not make them lose their sense of ukhuwah Islamiyah. Sometimes it is surprising, why the attitude of mutual respect for different opinions was not continued by people after the high priests of the four schools died (Grace, Alternative Islam, pp. 239-241).

Jalal is not interested in the fanaticism of the mazhab or any of the existing understandings, because according to him attachment to one of the mazhab can not only hinder thinking, but can also cause divisions, disbelieve, mutual disbelief, hostility and even war between fellow Muslims themselves (Grace, Emphasis) Morals, pp. 204-205). It is really worrying, Muslims by holding to the same source and guideline of life and the same purpose in life, but some of them have excessive suspicion, so that one of them blames one another and even leads to disbelievers to disbelieve only because of differences in mazhab, understandings and mazhab that holds on. Though the mazhab is the product of the mujtahid and not Sunnatullah. Mujtahid is a human being, so the products are certainly not absolute, they can be right and sometimes they can be wrong.

The mazhab is a product of Islamic law from the results of the mujtahid ijtihad, so it is not absolutely or necessarily a matter of guidance in Islam. The source of law in Islam is the Qur'an and Hadith, so Sunnatullah is the main legal basis and serves as a guide for Muslims. And if the Qur'an does not find the legal basis in a case, then return to the Hadith as the basis 
for the second Islamic law after the Qur'an. Kang Jalal looked, had a fight was not good, so if there is turmoil in the issue of fiqh, it is better for Muslims to return to the teachings of morals and put moral precedence over fiqh, leave fiqh to preserve morals or choose fiqh to be able to maintain fraternity rather than fiqh which can cause disunity Grace, Put the End Akhlah, p. 137). Imam Malik is one example of people who put morality before fiqh, in contrast to priests and adherents of the fiqh paradigm, their custom is to prioritize fiqh over morals. Imam Malik considers that piety does not lie in the school that is followed, but the piety or degree of someone depends on charity or what they do (Grace, Priority Morals, p. 25).

Jalal with his attitude of openness, he is not bound by the schools of schools that are strictly there, even Jalal invites Muslims to choose openness between schools, because Islam is a religion that teaches openness. Kang Jalal really yearns for openness, ukhuwah Islamiyah, noble character, virtuous deeds, compassion among people as exemplified by Ali bin Abi Talib in all patterns, attitudes and behavior of his life. Jalal is very impressed with Ali in every way. According to him, in Ali there is an attitude of openness and maintaining Islamic unity among fellow human beings, so that Jalal Ali is a role model and becomes his mecca (Malik and Ibrahim, Zaman, pp. 224-225).

The story of Jalal as a famous Muslim intellectual and preacher has changed much compared to when he was still in his young age. As a preacher who was active in giving lectures, sermons and Friday sermons at a young age, he received sharp criticism from various walks of life in Bandung, especially senior clerics whose connotations were of the understanding of the elderly. Jalal's lecture at that time was more focused on fiqh oriented, it seems that Jalal was still bound by his Muhammadiyah ideology and included fanatical Muhammadiyah cadres (Malik and Ibrahim, Zaman, p. 143). But Jalal has changed his way of thinking, he no longer wants to be bound by the school, he only wants to practice religion in accordance with the Qur'an and Sunnah (Grace, Priority Morals, p. 15).

Honestly, Jalal acknowledged the changes that had happened to him, the changes that occurred not only in his understanding of religion, but also in the way he practiced his religion. He replaced the fiqh paradigm with the moral paradigm, because fiqh is a collection of fatwas of scholars relating to syar'iah laws', while morals are sourced from the Qur'an and Hadith. According to his confession, at first many of the rituals carried out by the Islamic community were opposed, such as the circumcision Qablal Jum'ah prayers. The Azan Friday was only once, because the call to prayer before the Imam entered the mosque was never done by the Prophet, but he had forgotten all of that. Now he refers to the opinion of Imam Shafi'i, with his narration, Imam Shafi'i certainly knows more about the sunnah of the Prophet. Rather than himself (Grace, Put the Morals on, p. 9).

Jalal's frustration was expressed honestly in disguise on behalf of a young man, who mentioned it straightforwardly. However, now he regrets his past, his view of religion has changed, he wants to emulate the examples of the Imams of the school. If the Shafi'i priest can offer prayers behind Abu Hanifah, why is he who is lay in religion and is not recognized as a cleric even by the Majlis Ulama in his residence, can not be understood by the clerics in the village (Grace, Priority Morals, p. 31) .

\subsubsection{Spiritual Crisis of Modern Society}

The progress of science and technology, which is achieved in the West today, becomes a whip and valuable teaching for Muslims throughout the world. Muslims must review their weaknesses in the past few years, after experiencing their heyday from the VII ${ }^{\text {th }}$ Century to the 
XIII century, which was marked by the emergence of rational, scientific and philosophical ideas which developed rapidly among Muslims (Maskun, Sufism, p. 1).

According to Jalal, if Islam wants to return to playing its role as it has achieved, it is inevitable that Muslims must master science and technology. To answer this desire, a socialization of the love of science is needed to all Muslims. Muslims need to be aware of the importance of science based on correct ethical values. According to him, it is time for Muslims to start thinking about the importance of science and channel funds in the form of infaq, zakat, sadaqah and waqaf for science and technology development activities (Grace, Alternative Islam, p. 154).

In connection with Jalal's social activities in the field of scientific development as has been explained, even Jalal has established a foundation named after the Mutahhari Foundation in Bandung. The name of the foundation was attributed to a Shiite scholar and scholar of Iranian origin, Murthadha Mutahhari (Mutahhari, Ali bin Abi Talib, p. 6).

The existence of the foundation that was founded Jalal may not be said to be able to answer the demands of science, science and technology, because the subject matter or curriculum taught at his foundation is still focused on studying in the field of Islamic science, but Jalal has begun to work and devote his attention in the development effort quality of Muslims. Hopefully Jalal's efforts will be motivated by other parties from various walks of life in Indonesia to follow in Jalal's footsteps, by establishing other scientific institutions, both religious and science and technology. At the very least, all levels of Indonesian society are expected to grow in interest and attitude towards the importance of science and technology, so that they will prioritize the education of their children.

\subsection{The Sufistic Trends}

To the extent that can be understood from various writings of Sufism Kang Jalal, whether delivered through propaganda media, writing or electronically, it is rather difficult to clearly state the direction and tendencies of Sufism. However, if analyzed carefully from the Sufistic orientation conveyed by Jalal on various occasions, it will be clearly seen the tendency of Sufistic thinking. When analyzed carefully through a number of perspectives, among other things viewed from the point of moral Sufism, practice and philosophy, classical and modern Sufism, Sunni and Shiite Sufism and Sufi social dimension. Then it can be said that the tendency of Sufism is as follows:

\subsubsection{Sufism Akhlaki, Amali and Falsafi}

Islamic teachings include two dimensions, which in Sufi terms are often referred to as the exoteric dimension (lahiriyah) and the esoteric dimension (inner). These two dimensions are interrelated and cannot be separated from one another. The esoteric dimension is the Syari'ah which is clearly discussed through figh science, relating to the ritual procedures of Mahdah worship such as prayer, fasting and pilgrimage. While the esoteric dimensions are discussed through Sufism. As an example of prayer, in the exoteric dimension the prayer is discussed about the procedures and conditions for performing the prayer correctly, the esoteric dimension will see and talk about the nature of prayer itself and make the prayer as a way to Allah or the way a servant approaches yourself to the Creator. Likewise with other worship, both Mahdah worship and ghairu Mahdah worship. According to the Sufi version, the esoteric dimension becomes very important in human actions, and does not mean that the exoteric 
dimension must be abandoned, both dimensions must be of concern to a servant in carrying out worship to Allah properly and correctly.

Indeed, Allah has created man in the best form. This creation has become a human right from Allah. After accepting his rights, then Allah demands humans to worship and serve Him by carrying out various obligations and leaving all His prohibitions. Such devotion is often referred to as having the character of Allah. When associated with Sufism as intended by Jalal, which states that Sufism is morals or a number of manners that must be carried out by a servant towards Khalik, even between each other and with other natural surroundings, then it can be mentioned that the pattern of Jalal Sufism tends to Sufism and morals (Rosyidi, Da'wah, p. 12). Namely, the teachings of Sufism are more likely to morals and practice in an effort to get closer to Allah. In Jalal's understanding that Sufism is of two kinds, namely Sufism which is practical and theoretical. Sufism in practical terms includes moral and Sufi Sufism, while theoretical Sufism is Sufism in the form of philosophy. Based on the limitations of his knowledge, Jalal mentioned very little theoretical Sufism (Grace, Sufi Interpretation, p. Xvii).

\subsubsection{Classical and Modern Sufism}

As stated earlier, both in Jalal's attitude towards the ideas, opinions and thoughts of the ulama and intellectuals from various circles, Islam and non-Islam, he still appreciated it. Jalal is an intellectual figure who is meticulous and selective towards various opinions and thoughts that arise in society. In connection with the problem of Sufism in Salafism and neo Sufism, Jalal responded it fairly and wisely in accordance with the religious principles he understood. Sometimes Kang Jalal in his various Sufi studies, he referred to classical Sufism, by borrowing the opinions and thoughts of Sufi mysticism. And there are times when Jalal refers to the opinions and thoughts of temporary Sufis in expressing his views on Sufism. Thus, Jalal is not bound by any of the opinions, both those derived from classical Sufi scholars or those from modern Sufi scholars.

\subsubsection{Sunni Sufism and Shi'ism}

Sufism is not only known among Ahlussunnah wal jama'ah, but also developed among Shiites, which is called with 'irfan. The difference in terms used between the Sunni and Shiite schools is considered to be a common thing, even according to Jalal, the difference that occurs between the Sunni and Shiite schools in many respects is not too significant, precisely the differences that occur are actually many within the school's internal itself (Grace, Alternative Islam, p. 232). For Jalal, it is not important to differ in terms of the term Sufism in the Sunni and Irfan versions of Shi'ism, he considers that the two forms of Sufism are considered to be the same, as long as the two versions of Sufism are guided by the Qur'an and Sunnah. According to him, the method adopted could be in a variety of forms according to existing opinions, but the aim is the same.

\section{Conclusion}

Jalaluddin Rakhmat is a Muslim intellectual who is active, creative and dynamic and is very sensitive to various issues that develop in society, both in the fields of education, economics, politics, social, science and technology. And more specifically in the field of 
Islamic science in a good and deep, so that he is known as a scientist who is complex and multidisciplinary.

The treasures of his knowledge may be mentioned quite complex and multi-disciplinary which includes traditionalism, modernism, post modernism and even Kang Jalal's thoughts to touch on difficult and complicated issues, such as in the field of Sufism, so that Kang Jalal can be classified as a Muslim intellectual with universalism.

As a scholar of communication and politics, Jalal is known as a brilliant and creative communicator and politician, who is characterized by many of his scientific works that are produced and are very beneficial to the wider community, both works that are general in nature and that have an Islamic nuance. From a young age, Jalal had begun to actively preach and give religious teachings to the public with his mesmerizing rhetoric.

Kang Jalal's motivation to pursue Sufism was influenced by several factors: Psychological factors, preaching with Sufistic thinking; Sufistic ulama thought factor, Jalal likes to read Sufism literature; inter-school pro-counter factors, Jalal being neutral in thinking about differences between schools; the factor of spiritual crisis in modern society, it requires living comprehension, both vertically and horizontally, hablum minallah, hablum minannas and even hablum minal kauni perfectly.

\section{References}

Abu Wafa' al-Ghanimi At-Tafzani, Sufi dari Zaman ke Zaman: terj. Ahmad Rafi' Usmani, (Bandung, Pustaka, 1985).

Abuddin Nata, Akhlak Tasawuf, (Jakarta: Raja Grafindo. 2002).

Ali Maskun, Tasawuf sebagai pembebasan manusia Modern: Telaah Signifikansi Konsep Tradisional Islam Sayyed Hussein Nasr, (Surabaya: Pustaka Pelajar, 2003).

Annemarie Schimmel, Demensi Mistik dalam Islam, terj. Supardi Djoko Darmono at. al, (Jakarta: Pustaka Firdaus, 1986).

Azyumardi Azra, Islam Reformis: Dinamika Intelektual dan Gagasan, (Jakarta: Raja Grafindo Persada, 1999).

Dedy Djamaluddin dan Idi Subandi Ibrahim, Zaman Baru Islam Indonesia, Pemikiran dan Aksi Politik Abdurrahman Wahid, M. Amin Rais, Nurcholish Madjid, Jlaluddin Rakhmat, (Bandung: Zman Wacana Mulia, 1998).

Hamka, Tasawuf Modern, (Jakarta: Pustaka Panjimas, 1983).

Harun Nasution, Falsafat dan Mistisisme dalam Islam, (Jakarta: Bulan Bintang, 1992).

Jalaluddin Rakhmat, Renungan-Renungan Sufistik, Membuka Tirai Kegaiban, (Bandung: Mizan, 1994).

-------Menjembatani Kesenjangan Antar Mazhab, dalam Dedy Djamaluddin Malik dan Idi Subandy Ibrahim, Zaman Baru Islam, (Bandung: Remaja Rosdakarya, 1997).

Islam Alternatif, Ceramah-Ceramah di Kampus, (Bandung: Mizan, 2004).

Dahulukan Akhlak di atas Fikih, (Bandung: Manikmaya, 2002).

Tafsir Sufi al-Fatihah, (Bandung: Remaja Rosdakarya, 2000).

Tasawuf Dalam Alqur'an dan Sunnah, dalam Sukardi (ed), Kuliah-Kuliah Tasawuf, (Bandung: Pustaka Hidayah, 2000).

------- Reformasi Sufistik, Halaman Akhir Fitri Yathir, (Bandung: Pustaka Hidayah, 1999).

Murthadha Mthahhari, Ali bin Abi Thalib, Kekuatan dan Kesempurnaannya, terj. Zulfikar Ali, (Bnadung: Marja, 1995). 
M. Amin Syukur, Menggugat Tasawuf, Sufisme dan Tanggung Jawab Sosial Abad 21, (Yogyakarta: Pustaka Pelajar, 2002).

Rasyidi, Dakwah Sufistik Kang Jalal, Menentram Jiwa dan Mencerahkan Pikiran, (Jakarta: Paramadina, 2004).

Usman Said, et.al, Pengantar Ilmu Tasawuf, (Medan: IAIN-SU, 1981). 